\title{
Ocean acidification decreases plankton respiration: evidence from a mesocosm experiment
}

\author{
Kristian Spilling ${ }^{1,2}$, Allanah J. Paul ${ }^{3}$, Niklas Virkkala ${ }^{2}$, Tom Hastings ${ }^{4}$, Silke Lischka ${ }^{3}$, Annegret Stuhr ${ }^{3}$, \\ Rafael Bermúdez $^{3,5}$, Jan Czerny ${ }^{3}$, Tim Boxhammer ${ }^{3}$, Kai G. Schulz ${ }^{6}$, Andrea Ludwig ${ }^{3}$, and Ulf Riebesell ${ }^{3}$ \\ ${ }^{1}$ Marine Research Centre, Finnish Environment Institute, P.O. Box 140, 00251 Helsinki, Finland \\ ${ }^{2}$ Tvärminne Zoological Station, University of Helsinki, J. A. Palménin tie 260, 10900 Hanko, Finland \\ ${ }^{3}$ GEOMAR Helmholtz Centre for Ocean Research Kiel, Düsternbrooker Weg 20, 24105 Kiel, Germany \\ ${ }^{4}$ Department of Biology, University of Portsmouth, University House, Winston Churchill Avenue, Portsmouth PO1 2UP, UK \\ ${ }^{5}$ Facultad de Ingeniería Marítima, Ciencias Biológicas, Oceánicas y Recursos Naturales, ESPOL, Escuela Superior \\ Politécnica del Litoral, Guayaquil, Ecuador \\ ${ }^{6}$ Centre for Coastal Biogeochemistry, Southern Cross University, Military Road, East Lismore, NSW 2480, Australia
}

Correspondence to: Kristian Spilling (kristian.spilling@environment.fi)

Received: 27 November 2015 - Published in Biogeosciences Discuss.: 15 January 2016

Revised: 27 July 2016 - Accepted: 28 July 2016 - Published: 22 August 2016

\begin{abstract}
Anthropogenic carbon dioxide $\left(\mathrm{CO}_{2}\right)$ emissions are reducing the $\mathrm{pH}$ in the world's oceans. The plankton community is a key component driving biogeochemical fluxes, and the effect of increased $\mathrm{CO}_{2}$ on plankton is critical for understanding the ramifications of ocean acidification on global carbon fluxes. We determined the plankton community composition and measured primary production, respiration rates and carbon export (defined here as carbon sinking out of a shallow, coastal area) during an ocean acidification experiment. Mesocosms $\left(\sim 55 \mathrm{~m}^{3}\right)$ were set up in the Baltic Sea with a gradient of $\mathrm{CO}_{2}$ levels initially ranging from ambient ( $\sim 240 \mu \mathrm{atm})$, used as control, to high $\mathrm{CO}_{2}$ (up to $\sim 1330 \mu \mathrm{atm}$ ). The phytoplankton community was dominated by dinoflagellates, diatoms, cyanobacteria and chlorophytes, and the zooplankton community by protozoans, heterotrophic dinoflagellates and cladocerans. The plankton community composition was relatively homogenous between treatments. Community respiration rates were lower at high $\mathrm{CO}_{2}$ levels. The carbon-normalized respiration was approximately $40 \%$ lower in the high- $\mathrm{CO}_{2}$ environment compared with the controls during the latter phase of the experiment. We did not, however, detect any effect of increased $\mathrm{CO}_{2}$ on primary production. This could be due to measurement uncertainty, as the measured total particular carbon (TPC) and combined results presented in this special issue suggest that the reduced respiration rate translated
\end{abstract}

into higher net carbon fixation. The percent carbon derived from microscopy counts (both phyto- and zooplankton), of the measured total particular carbon (TPC), decreased from $\sim 26 \%$ at $t 0$ to $\sim 8 \%$ at $t 31$, probably driven by a shift towards smaller plankton $(<4 \mu \mathrm{m})$ not enumerated by microscopy. Our results suggest that reduced respiration leads to increased net carbon fixation at high $\mathrm{CO}_{2}$. However, the increased primary production did not translate into increased carbon export, and consequently did not work as a negative feedback mechanism for increasing atmospheric $\mathrm{CO}_{2}$ concentration.

\section{Introduction}

The ocean is a large sink of carbon dioxide $\left(\mathrm{CO}_{2}\right)$ and absorbs around $25 \%$ of annual anthropogenic $\mathrm{CO}_{2}$ emissions (Le Quéré et al., 2009). $\mathrm{CO}_{2}$ is a weak acid when dissolved in water, and the increasing global atmospheric $\mathrm{CO}_{2}$ concentration has reduced the average $\mathrm{pH}$ in the ocean by approximately 0.1 since the start of the Industrial Revolution (Orr, 2011). This $\mathrm{pH}$ reduction, with a concurrent increase in dissolved inorganic carbon, is called ocean acidification. Following the same trajectory, the $\mathrm{pH}$ could decline further by as much as 0.7 by 2300 (Zeebe et al., 2008). 
The topic of ocean acidification has received a lot of attention over the past decade. There is a relatively good understanding of the rate of change in $\mathrm{pH}$ and the effects on the ocean's carbon chemistry (Zeebe and Ridgwell, 2011). There are also a range of studies documenting the effects of decreasing $\mathrm{pH}$ on marine life, but the effect studied is often species- or ecosystem-specific and based on short-term perturbation experiments (Riebesell and Tortell, 2011). There are still a lot of uncertainties as to what effect ocean acidification has on biological processes.

The key driving force in marine biogeochemical element cycling is the planktonic community that occupies the sunlit surface of the ocean. Primary producers use the energy from sunlight to take up $\mathrm{CO}_{2}$ and fix carbon into organic compounds. Respiration is the opposite process, where organic carbon is oxidized, providing energy and releasing $\mathrm{CO}_{2}$. This takes place at all trophic levels, from bacteria through to zooplankton, fish and marine mammals. At steady state, production and respiration are balanced. On a global scale, there is presently a surplus of organic matter being produced in the upper ocean through photosynthesis. The extra organic carbon is exported out of the surface layers to the deep ocean, where it is sequestered for the foreseeable future, a process referred to as the biological carbon pump (Volk and Hoffert, 1985; Siegenthaler and Sarmiento, 1993; Ducklow et al., 2001). In the case of coastal seas, part of the carbon is buried at the sea floor (Dunne et al., 2007).

The greater the difference between primary production and respiration, the more carbon can potentially be exported, and ocean acidification has the potential to affect this balance. Generally, more $\mathrm{CO}_{2}$ stimulates photosynthetic carbon fixation, as $\mathrm{CO}_{2}$ becomes more readily available for the key photosynthetic enzyme RuBisCO (Falkowski and Raven, 2013); however, increased primary production at high $\mathrm{CO}_{2}$ concentration is not always recorded (Sobrino et al., 2014) and the response is variable between different taxa (Mackey et al., 2015). In cases where additional carbon is fixed, it may be excreted as dissolved organic carbon (DOC), providing carbon for bacterial growth, and also increasing bacterial respiration (Grossart et al., 2006; Piontek et al., 2010). Changes in $\mathrm{pH}$ might also directly affect both primary production (Spilling, 2007) and respiration (Smith and Raven, 1979).

The Baltic Sea is an almost landlocked sea with low alkalinity (Beldowski et al., 2010) and is thus particularly susceptible to variation in seawater $\mathrm{pH}$. Because of the reduced water exchange with the North Atlantic and the large catchment area (population $\sim 80$ million), it is also subjected to a range of other environmental pressures, in particular increased nutrient inputs from human activities, i.e., eutrophication. Eutrophication has led to increased primary production and chlorophyll $a$ (Chl $a$ ) biomass over the past decades in the Gulf of Finland (Raateoja et al., 2005), benefitting chrysophytes, chlorophytes and cyanobacteria (Suikkanen et al., 2007). Dense blooms of diazotroph cyanobacteria are com- mon in the summer, which further aggravates the eutrophication problem as nitrogen fixation introduces substantial amounts of new nitrogen into the system (Savchuk, 2005). The effect of ocean acidification on this type of system is largely unexplored. In order to investigate the effect of increased $\mathrm{CO}_{2}$ (and lower $\mathrm{pH}$ ) on primary production and total plankton respiration in the pelagic zone, we measured carbon fixation, oxygen consumption and export/sedimentation rates during a $\mathrm{CO}_{2}$-manipulation study set up in the Gulf of Finland, Baltic Sea (further references within this special issue).

\section{Materials and methods}

\subsection{Experimental setup}

Six pelagic mesocosms (approximately $55 \mathrm{~m}^{3}$ ) were moored at Storfjärden, on the southwest coast of Finland $\left(59^{\circ} 51.5^{\prime} \mathrm{N}\right.$, $23^{\circ} 15.5^{\prime} \mathrm{E}$ ), on 12 June 2012 . The water depth at the mooring site is approximately $30 \mathrm{~m}$ and the mesocosms extended from the surface down to $19 \mathrm{~m}$ depth. A more detailed description of the mesocosm bags and the experimental area can be found in Paul et al. (2015), and the data in Paul et al. (2016) and Spilling et al. (2016b).

On $t-5$ (17 June 2012, 5 days before the first $\mathrm{CO}_{2}$ enrichment), the mesocosms were bubbled with compressed air to break down any existing pycnocline and ensure homogeneous water mass distribution. Different $\mathrm{CO}_{2}$ concentrations in the bags were achieved by adding filtered $(50 \mu \mathrm{m}), \mathrm{CO}_{2}-$ saturated seawater. This was done stepwise in four separate additions to reduce the shock of rapid change in $\mathrm{pH}$ for the plankton community. The first addition took place after sampling on $t 0$; thus, $t 1$ was the first day with a $\mathrm{CO}_{2}$ treatment. The $\mathrm{CO}_{2}$-enriched water was evenly distributed over the upper $17 \mathrm{~m}$ using a specially designed distribution device, i.e., "spider" (Riebesell et al., 2013). Two controls and four treatment mesocosms were used. Filtered water (with ambient $\mathrm{CO}_{2}$ concentration) was added to the control mesocosms at the time when $\mathrm{CO}_{2}$ was manipulated in the treatment mesocosms. The $\mathrm{CO}_{2}$ fugacity gradient on $t 4$, after the four additions, ranged from ambient $\left(\sim 240 \mu \mathrm{atm} f \mathrm{CO}_{2}\right)$ in the two control mesocosms (M1 and M5) to $\sim 1650 \mu$ atm $f \mathrm{CO}_{2}$, but we used the average $f \mathrm{CO}_{2}$ throughout the relevant part of this experiment (from $t 1-t 31)$ to denote the different treatments: 346 (M1), 348 (M5), 494 (M7), 868 (M6), 1075 (M3) and $1333 \mu \mathrm{atm} f \mathrm{CO}_{2}(\mathrm{M} 8)$. On $t 15$, additional $\mathrm{CO}_{2}$-enriched seawater was added to the upper $7 \mathrm{~m}$ in the same manner as the initial enrichment to counteract outgassing of $\mathrm{CO}_{2}$. The mesocosm bags were regularly cleaned to prevent wall growth. A more detailed description of the treatment and cleaning can be found in Paul et al. (2015).

Mesocosm sampling was carried out every day (or every second day for some variables) in the morning. Two different depth-integrated water samples $(0-10$ and $0-17 \mathrm{~m})$ 
were taken using integrating water samplers (IWS, HYDROBIOS, Kiel). The water was collected into plastic carboys $(10 \mathrm{~L})$ and brought to the laboratory for subsampling and subsequent analysis of plankton community composition and carbon concentration, as well as for respiration and primary production incubations. Sub-samples for primary production and respiration measurements were treated and stored minimizing the contact with air in order to prevent any gas exchange.

Settling particles were quantitatively collected in the sediment traps at the bottom end of the mesocosm units at $19 \mathrm{~m}$ depth. Every $48 \mathrm{~h}$ the accumulated material was vacuumpumped through a silicon tube to the sea surface and transferred into $5 \mathrm{~L}$ glass bottles for transportation to the laboratory. For a more detailed description of the sampling procedure and sample processing of the sediment see Boxhammer et al. (2016).

\subsection{Phytoplankton community}

Phytoplankton cells were counted in $50 \mathrm{~mL}$ subsamples, which were fixed with acidic Lugol's iodine solution (1\% final concentration) with an inverted microscope (Zeiss Axiovert 100) after Utermöhl (1958). The cells $>20 \mu \mathrm{m}$ were counted either from half of the chamber at 100 -fold or on three to four strips at 200-fold magnification. Filamentous cyanobacteria were counted in $50 \mu \mathrm{m}$ length units. Cells 12 $20 \mu \mathrm{m}$ were counted at half of the chamber at 200 -fold magnification, and cells $4-12 \mu \mathrm{m}$ were counted at 400 -fold magnification on two radial strips. The phytoplankton counts of the smaller size classes $(<20 \mu \mathrm{m})$ stopped on $t 29$, and these results have been used together with the $t 31$ results for larger $(>20 \mu \mathrm{m})$ phytoplankton as the end date of the experiment. Further details can be found in Bermúdez et al. (2016)

Phytoplankton, heterotrophic dinoflagellates and protozoa were identified with the help of Tomas (1997), Hoppenrath et al. (2009) and Kraberg et al. (2010). Biovolumes of counted plankton cells were calculated according to Olenina et al. (2006) and converted to cellular organic carbon quotas by the equations of Menden-Deuer and Lessard (2000).

\subsection{Microzooplankton community}

Ciliates were enumerated from $50 \mathrm{~mL}$ subsamples every second day with a Zeiss Axiovert 100 inverted microscope (Utermöhl 1958) at 200-fold magnification. At high cell numbers ( $>400$ cells), half the bottom plate area was counted. If less than 400 cells were found in the first half of the bottom plate area, the entire chamber was counted. Rare species were counted on the whole bottom plate. Ciliates were identified to the lowest possible taxonomic level (genus/species) according to Setälä et al. (1992) and Telesh et al. (2009) as well as description plates found on the Planktonic Ciliate Project website (http://ciliate.zooplankton.cn/). For more details see Lischka et al. (2015) in this issue.

\subsection{Mesozooplankton community}

The term zooplankton includes here all metazoan species, i.e., organisms belonging, strictly speaking, to either the micro- or mesozooplankton. Zooplankton samples were collected by net hauls from $17 \mathrm{~m}$ depth with an Apstein net of $17 \mathrm{~cm}$ diameter and $100 \mu \mathrm{m}$ mesh size. After closing of the mesocosm bags, zooplankton samples were taken prior to the $\mathrm{CO}_{2}$ addition on $t 0$ and at $t 17$ and $t 31$ (there were also other sampling days for zooplankton, but these are not included here). Samples were preserved in $70 \%$ ethanol. Zooplankton was counted assuming $100 \%$ filtering efficiency of the net. The samples were divided with a Folsom plankton splitter $(1: 2,1: 4,1: 8,1: 16$, and $1: 32)$ and aliquots were counted using a WILD M3B stereo microscope. Abundant species/taxa were enumerated from subsamples (> 30 individuals in an aliquot), while less abundant and rare species/taxa were counted from the whole sample. For more details on mesozooplankton collection, processing and species determination, see Lischka et al. (2015). Carbon biomass (CB) in $\mu \mathrm{mol} \mathrm{CL}^{-1}$ was calculated using the displacement volume (DV) and the equation of Wiebe (1988):

$(\log \mathrm{DV}+1.429) / 0.82=\log \mathrm{CB}$.

\subsection{Total particulate carbon}

Samples for total particulate carbon (TPC) measurements were subsampled from $10 \mathrm{~L}$ carboys and filtered onto GF/F filters (Whatman, nominal pore size of $0.7 \mu \mathrm{m}$, diameter $=25 \mathrm{~mm})$ under reduced vacuum $(<200 \mathrm{mbar})$. Sampling for TPC occurred every second day from $t-3$ until the end of the experiment. Filters were stored in glass Petri dishes at $-20^{\circ} \mathrm{C}$ directly after filtration until preparation of samples for analyses. Petri dishes and filters were combusted at $450^{\circ} \mathrm{C}$ for $6 \mathrm{~h}$ before use.

Samples were analyzed for TPC (organic + inorganic) as no acidifying step was made to remove particulate inorganic carbon. Filters were dried at $60^{\circ} \mathrm{C}$ and packed into tin capsules and stored in a desiccator until analysis on an elemental analyzer (EuroEA) as described by Sharp (1974).

The particles collected from the sediment traps were allowed to settle down in the sampling flasks at in situ temperature before separation of supernatant and the dense particle suspension at the bottom. TPC content of the supernatant was analyzed from $10-50 \mathrm{~mL}$ subsamples as described above for water column measurements. The dense particle suspension was concentrated by centrifugation, then freeze-dried and ground to a very fine powder of homogeneous composition. From this material, small subsamples of $1-2 \mathrm{mg}$ were transferred into tin capsules and TPC content was analyzed analogously to the supernatant and water column samples. Vertical carbon flux was calculated from the two measurements and is given as the daily amount of TPC (mmol) collected in the sediment traps per square meter of mesocosm surface area $\left(3.142 \mathrm{~m}^{2}\right)$. 


\subsection{Dissolved inorganic carbon}

Samples for dissolved inorganic carbon (DIC) were gently pressure-filtered (Sarstedt Filtropur $0.2 \mu \mathrm{m}$ ) before measurements to remove all particulates. DIC concentrations were determined by infrared absorption (LICOR LI-7000 on an AIRICA system, Marianda). Four $(2 \mathrm{~mL})$ replicates were measured, and the final DIC concentration was calculated from the mean of the three most consistent samples.

\subsection{Plankton community respiration}

Samples for respiration rate measurements were subsampled from the depth integrated sample from the entire water column $(0-17 \mathrm{~m})$. Oxygen was measured using a fiber optical dipping probe (PreSens, Fibox 3), which was calibrated against anoxic $\left(0 \% \mathrm{O}_{2}\right.$, obtained by adding sodium dithionite) and air-saturated water (obtained by bubbling sampled water with air for $5 \mathrm{~min}$ followed by $15 \mathrm{~min}$ of stirring with a magnetic stirrer). The final $\mathrm{O}_{2}$ concentration was calculated using the Fibox 3 software including temperature compensation.

We filled three replicate $120 \mathrm{~mL} \mathrm{O}_{2}$ bottles (without headspace) for each mesocosm. After the initial $\mathrm{O}_{2}$ determination, the bottles were put in a dark, temperature-controlled room, set to the ambient water temperature at the surface. The $\mathrm{O}_{2}$ concentration was determined again after an incubation period of $48 \mathrm{~h}$, and the oxygen consumption (i.e., respiration rate) was calculated from the difference between the $\mathrm{O}_{2}$ concentration before and after the incubation period. Respiration rates were measured every day $t-3$ to $t 31$, with the exception of days $t 2$ and $t 14$ because of technical problems.

\subsection{Primary production}

Primary production was measured using radio-labeled $\mathrm{NaH}^{14} \mathrm{CO}_{3}$ (Steeman-Nielsen, 1952) from the $0-10 \mathrm{~m}$ depth integrated sample. The rational for using the upper $(0-10 \mathrm{~m})$ part of the mesocosm was the low light penetration depth, and $0-10 \mathrm{~m}$ was representative of the euphotic zone. The water was gently filled into 12 small $(8 \mathrm{~mL})$ scintillation vials per mesocosm, and $10 \mu \mathrm{L}$ of ${ }^{14} \mathrm{C}$ bicarbonate solution (DHI Lab; $20 \mu \mathrm{Ci} \mathrm{mL}^{-1}$ ) was added. The vials were filled completely, and after adding the cap there was only a very small (2-3 mm) air bubble remaining corresponding to $\sim 0.1 \%$ of total volume.

Duplicate samples for each mesocosm were incubated just below the surface and at 2, 4, 6, 8 and $10 \mathrm{~m}$ depths for $24 \mathrm{~h}$ on small incubation platforms moored next to the mesocosms (Fig. S1 in the Supplement). In addition, a dark incubation (vials covered with aluminum foil) was carried out at the same location at $11 \mathrm{~m}$ depth.

After incubation, $3 \mathrm{~mL}$ of the sample was removed from each vial and acidified with $100 \mu \mathrm{L}$ of $1 \mathrm{~mol} \mathrm{~L}^{-1} \mathrm{HCl}$ and then left without a lid for $24 \mathrm{~h}$ to ensure removal of remaining inorganic ${ }^{14} \mathrm{C}$. Four milliliters of scintillation cocktail (Instagel Plus, Perkin Elmer) was added, and the radioactivity was determined using a scintillation counter (Wallac 1414, Perkin Elmer). Primary production was calculated knowing the ${ }^{14} \mathrm{C}$ incorporation (with dark values subtracted) and the fraction of the ${ }^{14} \mathrm{C}$ addition to the total inorganic carbon pool according to Gargas (1975). The primary production incubations were set up at the same time as the respiration incubations, but here we missed measurements for two periods, $t 1-t 3$ and $t 6-t 8$, due to loss of the incubation platform.

\subsection{Data treatment}

The average of the three respiration bottles was used to calculate the respiration rate. There were 2 days without measurements, $t 2$ and $t 14$, and for these days we estimated the respiration rate by using the average of the day before and after this day. TPC was measured only every second day, therefore for the days without TPC measurements we normalized respiration to average TPC from the day before and the day after the respiration measurement.

The cumulative respiration was calculated by adding the total oxygen consumption for each day. When evaluating the data, there were two clear periods emerging from the experiment: the initial period $t 0$ to $t 16$ (Phase I) and the period from $t 17$ to $t 31$ (Phase II), when the effect of the $\mathrm{CO}_{2}$ addition was more evident. This division was also seen in, for example, Chl $a$ and temperature (Paul et al., 2015). Using the respiration data from Phase II we calculated the average respiration for each treatment by linear regression. From the linear regression, the standard error (SE) from the residuals and the coefficient of determination $\left(R^{2}\right)$ were calculated, in addition to a statistical test comparing the linear regression with a flat line, using SigmaPlot software.

The areal primary production was calculated based on a simple linear model of the production measurements from the different depths (Fig. S2). The cumulative primary production was carried out similar to respiration, but as the two missing periods were $>1$ day, we did not estimate missing values, and the final cumulative production is therefore a slight underestimate (missing 6 days of production). We normalized the production data to the TPC in the euphotic zone, defined by the areal production model (Fig. S2).

From the two different phases of the experiment (Phases I and II; $t 0-t 16$ and $t 17-t 31$, respectively) we calculated the average for the different parameters and SE, with 9 and 7 sampling points during Phase I and II, respectively.

\section{Results}

\subsection{Phytoplankton community composition}

The phytoplankton community in the mesocosms was dominated by dinoflagellates, cyanobacteria, diatoms, chrysophytes and chlorophytes at the start of the experiment 
(Fig. 1). The two latter groups consisted almost exclusively of small cells $(<20 \mu \mathrm{m})$. There was an initial increase in phytoplankton biomass from an average of $3 \mu \mathrm{mol} \mathrm{CL^{-1 }}$ to a maximum of $\sim 4.1 \mu_{\mathrm{mol} \mathrm{C} \mathrm{L}}^{-1}$ in the two controls (M1 and M5), but at the end of Phase I ( $t 0-t 16)$ the biomass had declined and at $t 17$ it ranged between 3.2 and $3.5 \mu \mathrm{mol} \mathrm{CL^{-1 }}$. During Phase I, large $(>20 \mu \mathrm{m})$ diatoms decreased in abundance and euglenophytes increased from a negligible group initially $(0.5 \%$ of the biomass) to constituting $15-25 \%$ of the autotrophic biomass at $t 17$. It was, however, the small $(<20 \mu \mathrm{m})$ phytoplankton cells (small diatoms, chrysophytes and chlorophytes) that made up the majority (70-80\%) of the counted autotroph biomass during Phase I.

During Phase II (t17-t31), there was a decline in phytoplankton biomass to $0.5-1 \mu \mathrm{mol} \mathrm{CL^{-1 }}$ and at $t 31$ dinoflagellates had become the dominating group in all treatments except at the highest $\mathrm{CO}_{2}$ level. Cyanobacteria and chlorophytes were also abundant and the dominating groups in the highest $\mathrm{CO}_{2}$. There was no consistent difference between phytoplankton communities in the different $\mathrm{CO}_{2}$ treatments, but dinoflagellate abundance was lower in the highest $\mathrm{CO}_{2}$ treatment (M8), and consequently the total phytoplankton biomass was lower in this treatment at $t 31$. The relative increase in large dinoflagellates decreased the contribution of the smaller autotroph size class $(4-20 \mu \mathrm{m})$ to $40-60 \%$ of the counted phytoplankton biomass at $t 31$.

\subsection{Zooplankton community composition}

Protozoans, ciliates and heterotrophic dinoflagellates dominated the microzooplankton and constituted a major part $\left(2.8 \mu \mathrm{mol} \mathrm{C} \mathrm{L}{ }^{-1}\right)$ of the whole zooplankton community at the start of the experiment (Fig. 2). Protozoans, dominated by the choanoflagellate Calliacantha natans, decreased from the initial high concentrations during Phase I, in particular in the M1 control bag. The photosynthesizing Myrionecta rubra (i.e., Mesodinium rubrum) made up approximately half of the ciliate biomass at $t 0$, but both this species and the total biomass of ciliates decreased during Phase I. The biomass of heterotrophic dinoflagellates was relatively stable throughout Phase I but started to decrease during Phase II.

The mesozooplankton community was initially dominated by copepods, cladocerans and rotifers (Fig. 2). The average initial biomass was $0.05 \mu \mathrm{mol} \mathrm{CL}{ }^{-1}$ and increased to $0.13 \mu \mathrm{mol} \mathrm{CL}{ }^{-1}$ at $t 17$. During Phase I, copepods became the dominating group with $>50 \%$ of the mesozooplankton biomass. In Phase II of the experiment, mesozooplankton biomass increased and was on average $0.27 \mu \mathrm{mol} \mathrm{C} \mathrm{L}{ }^{-1}$ at $t 31$. This was caused by an increase in cladocerans, mainly Bosmina sp., whereas copepod biomass was more constant over the course of the experiment. The population peak of Bosmina sp. had slightly different timing in the different mesocosms but was higher in the mesocosms with added $\mathrm{CO}_{2}$, except for the highest $\mathrm{CO}_{2}$ addition (M8).

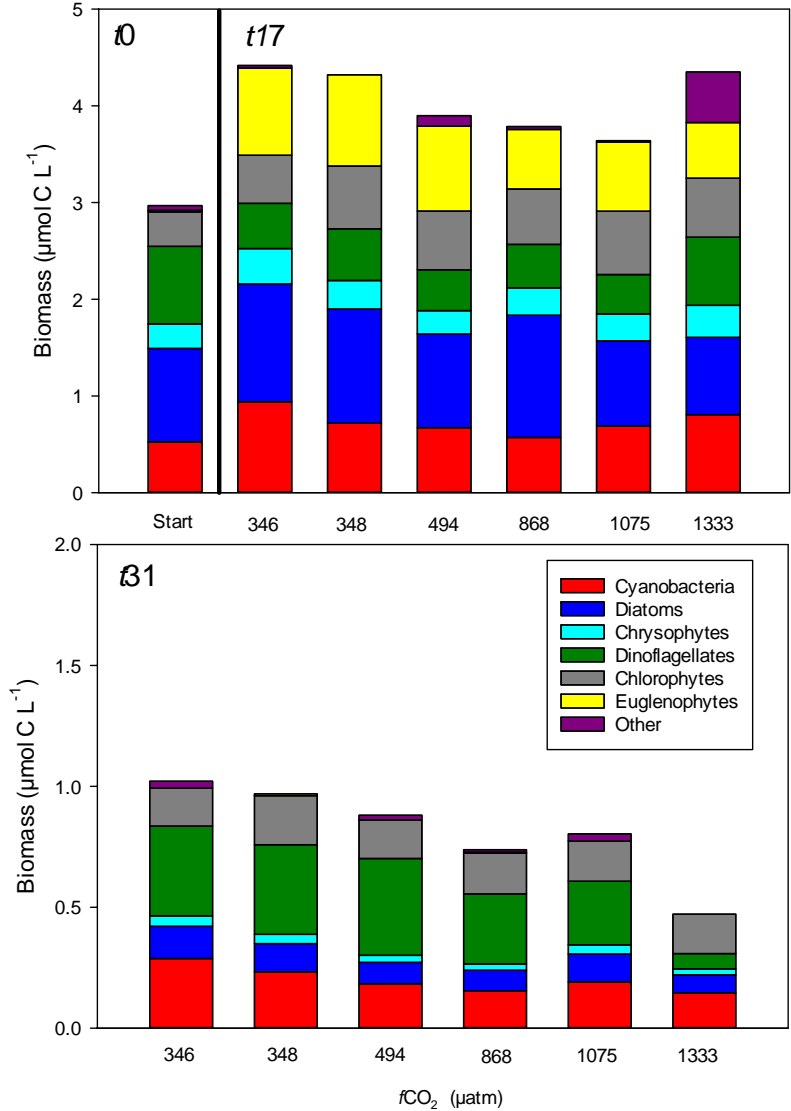

Figure 1. The main phytoplankton groups at the start of the experiment, $t 0$, and $t 17$ (upper panel) and $t 31$ (lower panel). The initial $(t 0)$ was the average of all mesocosm bags. A more detailed description of the temporal development in the phytoplankton community can be found in Bermúdez et al. (2016).

\subsection{Total particulate carbon and export of carbon}

Average TPC was $22.5 \mu \mathrm{mol} \mathrm{C} \mathrm{L}{ }^{-1}$ at the beginning of the experiment, and after an initial increase to $32 \mu \mathrm{mol} \mathrm{C} \mathrm{L}^{-1}$ it decreased to $19.2 \mu \mathrm{mol} \mathrm{C} \mathrm{L}^{-1}$ at $t 17$ (Fig. 3). In the beginning of Phase II it was relatively stable and with no clear effect of $\mathrm{CO}_{2}$ treatment, but at the end of the study period $(t 31)$ there was more TPC in the higher $\mathrm{CO}_{2}$ treatments, and the increase in TPC during Phase II was highest in the $\mathrm{CO}_{2}$ additions (Table 1). At $t 31$ the average TPC was $19.9 \mu \mathrm{mol} \mathrm{CL}^{-1}$, ranging from $18.9 \pm 0.6(\mathrm{SE}) \mu \mathrm{mol} \mathrm{CL^{-1 }}$ in the two controls to $22.1 \mu \mathrm{mol} \mathrm{C} \mathrm{L}{ }^{-1}$ in the highest $\mathrm{CO}_{2}$ treatment.

The carbon accounted for by biologically active organisms counted in the microscope (phytoplankton and zooplankton) was initially $26 \%$ of the TPC. At $t 17$ and $t 31$ this percentage decreased to $\sim 20$ and $\sim 8 \%$, respectively.

The export of carbon, defined here as carbon settling out of the mesocosms, decreased during the experiment, and there was no effect of $\mathrm{CO}_{2}$ concentration. The average export of TPC was in the range of $6.1-7.4 \mathrm{mmol} \mathrm{C} \mathrm{m}^{-2} \mathrm{~d}^{-1}$ during 
Table 1. Average net primary production (NPP), total respiration (TR) and exported total particulate carbon (Exp mmol C m ${ }^{-2} \mathrm{~d}^{-1} \pm \mathrm{SE}$ during Phase I and Phase II of the experiment. The pool of total particulate carbon (TPC) is the average during the two periods in mmol $\mathrm{C} \mathrm{m}^{-2} \pm \mathrm{SE}$. The standard error was calculated throughout the period: Phase I, $n=9$; Phase II, $n=7$. NPP and TR were corrected for the missing measuring days during Phase I. TR was measured as $\mathrm{O}_{2}$ consumption and for comparison with carbon fixation we used a respiratory quotient (RQ) of 1 .

\begin{tabular}{|c|c|c|c|c|c|c|}
\hline \multicolumn{7}{|l|}{ Phase I $(t 0-t 16)$} \\
\hline $\mathrm{CO}_{2}$ treatment $\left(\mu \mathrm{atm} f \mathrm{CO}_{2}\right)$ & 346 & 348 & 494 & 868 & 1075 & 1333 \\
\hline NPP & $4.8 \pm 0.8$ & $11.4 \pm 2.1$ & $14.9 \pm 3.6$ & $12.3 \pm 2.3$ & $11.3 \pm 2.4$ & $14.5 \pm 2.7$ \\
\hline TR & $107 \pm 9$ & $82 \pm 7$ & $81 \pm 6$ & $80 \pm 8$ & $75 \pm 8$ & $74 \pm 8$ \\
\hline $\operatorname{Exp}_{\text {TPC }}$ & $6.6 \pm 0.10$ & $5.6 \pm 0.04$ & $5.4 \pm 0.07$ & $6.0 \pm 0.07$ & $5.6 \pm 0.06$ & $6.0 \pm 0.05$ \\
\hline TPC & $410 \pm 25$ & $385 \pm 25$ & $402 \pm 31$ & $415 \pm 33$ & $408 \pm 27$ & $424 \pm 38$ \\
\hline \multicolumn{7}{|l|}{ Phase II $(t 17-t 31)$} \\
\hline $\mathrm{CO}_{2}$ treatment $\left(\mu \mathrm{atm} f \mathrm{CO}_{2}\right)$ & 346 & 348 & 494 & 868 & 1075 & 1333 \\
\hline NPP & $3.8 \pm 0.6$ & $11.2 \pm 1.9$ & $10.8 \pm 2.0$ & $14.3 \pm 2.8$ & $10.4 \pm 2.1$ & $12.0 \pm 2.5$ \\
\hline TR & $140 \pm 7$ & $127 \pm 5$ & $103 \pm 3$ & $103 \pm 4$ & $101 \pm 5$ & $86 \pm 4$ \\
\hline $\operatorname{Exp}_{\text {TPC }}$ & $3.3 \pm 0.08$ & $2.6 \pm 0.06$ & $2.5 \pm 0.08$ & $2.6 \pm 0.06$ & $2.8 \pm 0.07$ & $2.9 \pm 0.06$ \\
\hline TPC & $301 \pm 11$ & $313 \pm 11$ & $305 \pm 16$ & $316 \pm 7$ & $317 \pm 5$ & $326 \pm 10$ \\
\hline
\end{tabular}

Phase I (Table 1). This decreased to $2.5-3.3 \mathrm{mmol} \mathrm{C} \mathrm{m}^{-2} \mathrm{~d}^{-1}$ during Phase II.

\subsection{Primary production and respiration}

There was no clear effect of $\mathrm{CO}_{2}$ addition on primary production (Fig. 4). There were relatively large daily variations in depth-integrated primary production depending on the light environment, and days with clear skies and more light increased carbon fixation. One of the control bags (M1) had clearly lower primary production from the very start of the experiment, and this was evident even before the initiation of the $\mathrm{CO}_{2}$ addition (Fig. 4). The average production during the whole experiment was $3.67 \pm 0.42(\mathrm{SE}) \mathrm{mmol} \mathrm{C} \mathrm{m}^{-2} \mathrm{~d}^{-1}$ in $\mathrm{M} 1$, and for all other bags $10.5 \pm 0.67$ (SE) $\mathrm{mmol} \mathrm{C} \mathrm{m}^{-2} \mathrm{~d}^{-1}$. Production on clear, sunny days was (except for M1) approximately $25 \mathrm{mmol} \mathrm{C} \mathrm{m}^{-2} \mathrm{~d}^{-1}$. The general pattern in areal primary production was similar to TPC-normalized production (Table 1). Cumulative production values in $\mathrm{mol} \mathrm{C} \mathrm{m}^{-2}$ are presented in the Supplement (Fig. S3).

The respiration rate was higher in the ambient than the high- $\mathrm{CO}_{2}$ treatments (Fig. 5). In one of the two controls (M1), the respiration rate was clearly higher compared to all other treatments from the beginning of the experiment. The respiration rate in the other control (M5) increased approximately 2 weeks later than the $\mathrm{CO}_{2}$ treatments. After $t 17$, the mesocosm with highest $\mathrm{CO}_{2}$ concentration (average of $1333 \mu \mathrm{atm} f \mathrm{CO}_{2}$ ) started to have lower cumulative respiration compared to those with intermediate $\mathrm{CO}_{2}$ levels (494-1075 $\mu$ atm $\left.f \mathrm{CO}_{2}\right)$. After another week $(\sim t 27)$, differences between the intermediate $\mathrm{CO}_{2}$ treatments became apparent. At the end of Phase II ( $t 20-t 31)$, there was a $40 \%$ difference in respiration rate between the lowest and highest $f \mathrm{CO}_{2}$ treatments (slope $-0.0002 ; p=0.02 ; R^{2}=0.77$;
Fig. 6). The volumetric respiration during Phase II was 7.6 and $7.1 \mu \mathrm{molO}_{2} \mathrm{~L}^{-1} \mathrm{~d}^{-1}$ for the two controls, and 4.7$5.7 \mu \mathrm{mol} \mathrm{O} \mathrm{L}^{-1} \mathrm{~d}^{-1}$ for the $\mathrm{CO}_{2}$ treatment mesocosms. Outside the mesocosms, at ambient $\mathrm{CO}_{2}$ concentration (average of $343 \mu \mathrm{atm} f \mathrm{CO}_{2}$ but with larger variability than inside the mesocosms), the carbon normalized respiration rate was lower than inside the mesocosms and the cumulative, carbonnormalized respiration was approximately half of that measured in the control bags at the end of the experiment (Fig. 5). The general pattern of lower respiration rates at high $\mathrm{CO}_{2}$ concentration was the same without normalization to TPC (Table 1, Fig. S4).

\section{Discussion}

\subsection{Plankton community}

The particulate and dissolved standing stocks during this experiment are presented in Paul et al. (2015). In the initial Phase I of the experiment, the Chl $a$ concentration was relatively high $\left(\sim 2 \mu \mathrm{g} \mathrm{Chl} a \mathrm{~L}^{-1}\right)$, but it started to decrease during Phase II, reaching $\sim 1 \mu \mathrm{g} \mathrm{Chl} a \mathrm{~L}^{-1}$ at $t 31$ in all of the treatments. During this transition there was a shift in the plankton community with decreasing phytoplankton and microzooplankton, as well as increasing abundance of mesozooplankton, primarily cladocerans (Figs. 1 and 2).

The phytoplankton community composition was dominated by common species in the area (Hällfors, 2004). In the latter part (Phase II), the relative dominance by dinoflagellates was mainly due to reduction in biomass of the other groups, with the exception of the highest $\mathrm{CO}_{2}$ concentration, where the dinoflagellates also decreased in abundance. Dinoflagellates are generally favored in low turbulence (Margalef, 1978; Smayda and Reynolds, 2001) and were proba- 

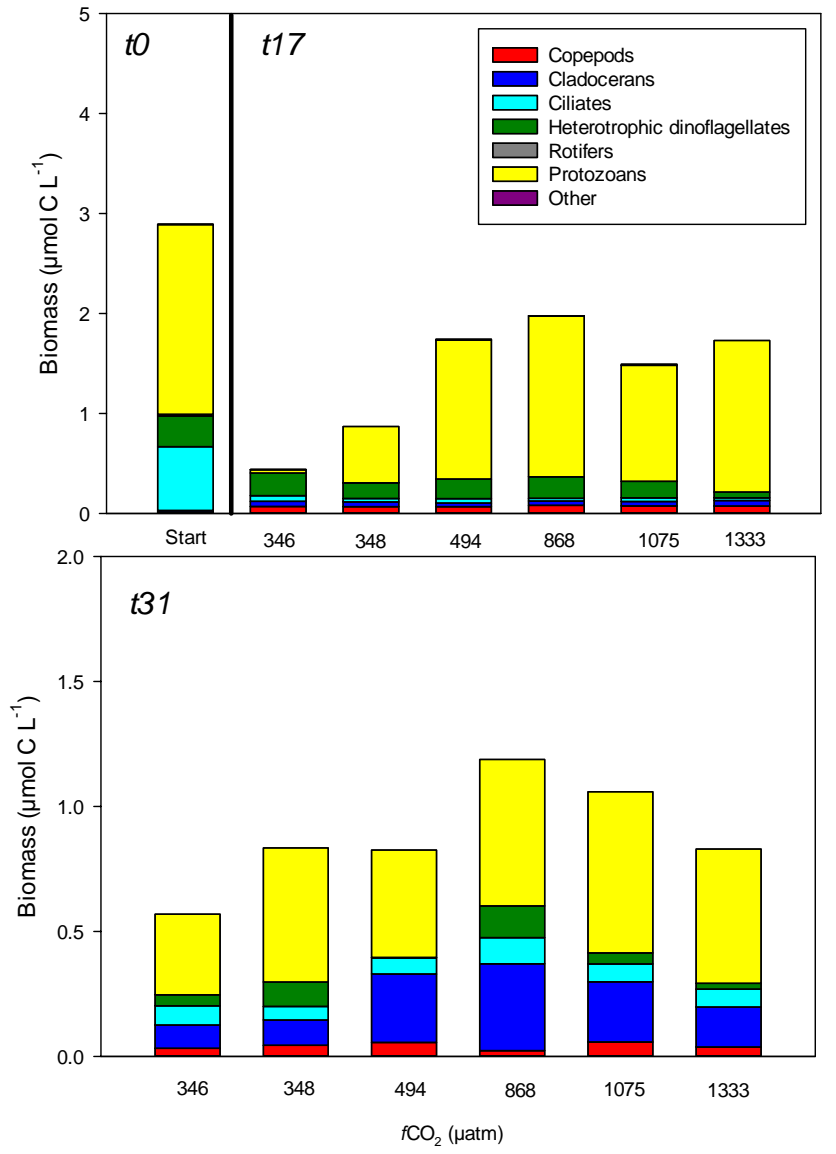

Figure 2. The main micro- and mesozooplankton groups at the start of the experiment, $t 0$, and $t 17$ (upper panel) and $t 31$ (lower panel). The initial period $(t 0)$ was the average of all mesocosm bags. A more detailed description of the temporal development in the zooplankton community can be found in Lischka et al. (2015).

bly benefitting from the relative stable conditions within the mesocosms. Blooms of filamentous cyanobacteria do occur in the area, but they did not develop within the mesocosms. The relatively low temperature (mostly $<15^{\circ} \mathrm{C}$; Paul et al., 2015) could be a reason for that (Kanoshina et al., 2003).

Protozoans, ciliates and heterotrophic dinoflagellates dominated the microzooplankton, and Myrionecta rubra initially made up a large proportion of the ciliates. M. rubra can be regarded as mixotrophic and would also have contributed to the carbon fixation (Johnson et al., 2006). Copepods and cladocerans initially dominated the mesozooplankton, and during Phase II cladocerans became the dominant mesozooplankton group. Cladocerans are typically predominant in freshwater, but in the brackish Baltic Sea they can be common, in particular when stability in the water column is high (Viitasalo et al., 1995).

The combined phyto- and zooplankton carbon derived from microscope counts decreased during the experiment. TPC did not decrease to the same extent, and the percent-

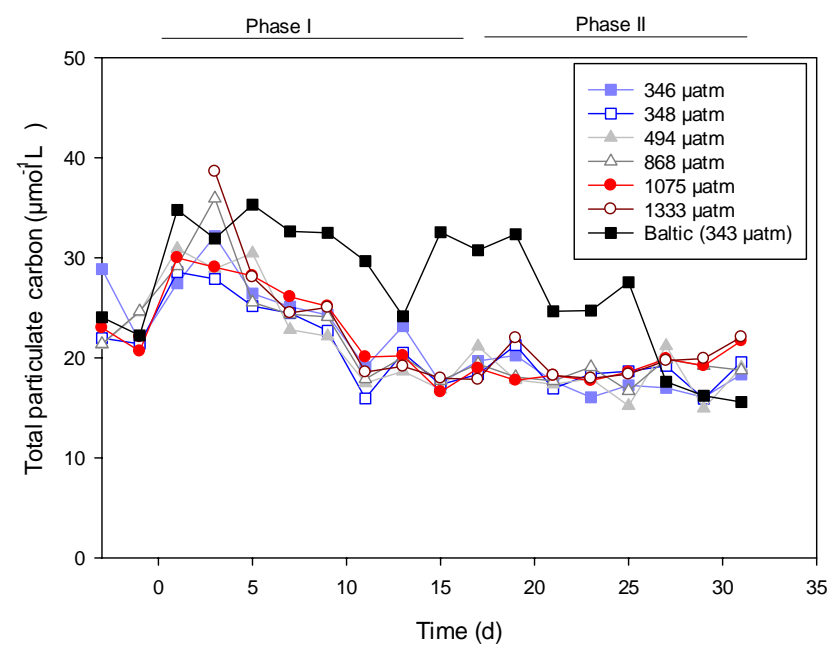

Figure 3. The development of TPC during the experiment.

age microscope-derived carbon of TPC decreased from $26 \%$ at $t 0$ to only $\sim 8 \%$ of the measured TPC at $t 31$. These numbers are not directly comparable, as detritus, i.e., non-living carbon particles, is included in TPC. However, any large aggregates sink rapidly and are not expected to have contributed much to the TPC. The reduction of microscopy-derived carbon to TPC indicates rather increasing importance of smaller size classes $(<4 \mu \mathrm{m})$, not enumerated by the microscope counts. This conclusion is also supported by flow cytometer data from this experiment (Crawfurd et al., 2016), increasing uptake of $\mathrm{PO}_{4}$ by the $<3 \mu \mathrm{m}$ fraction (Nausch et al., 2016) and the increasing proportion of the smallest $(<2 \mu \mathrm{m})$ size class of Chl $a$ (Paul et al., 2015).

\subsection{Primary production and respiration}

Primary production and respiration rates were comparable to values obtained under similar conditions in the area (Kivi et al., 1993). There are relatively few records of respiration, but the measured respiration rates in the control bags were similar to the average respiration rate obtained for a range of coastal waters of $7.4 \pm 0.54 \mathrm{mmol} \mathrm{O}_{2} \mathrm{~m}^{-3} \mathrm{~d}^{-1}(n=323$; Robinson and Williams, 2005). The incubation period we used for primary production measurements $(24 \mathrm{~h})$ provides production rates close to net production (Marra, 2009).

The higher respiration and lower production in the M1 control bag was probably connected, i.e., higher respiration led to lower net carbon fixation; however, the reason for the M1 bag being very different from the very start is not clear. Most of the other variables were similar in the M1 bag compared to the rest (Paul et al., 2015), but there was some indication of difference in community. In particular, protozoans were lower in the M1 bag compared with the rest of the mesocosms throughout the experiment. However, judging from the development in carbon pools (Paul et al., 2015) and fluxes in the system (Spilling et al., 2016a), the NPP mea- 


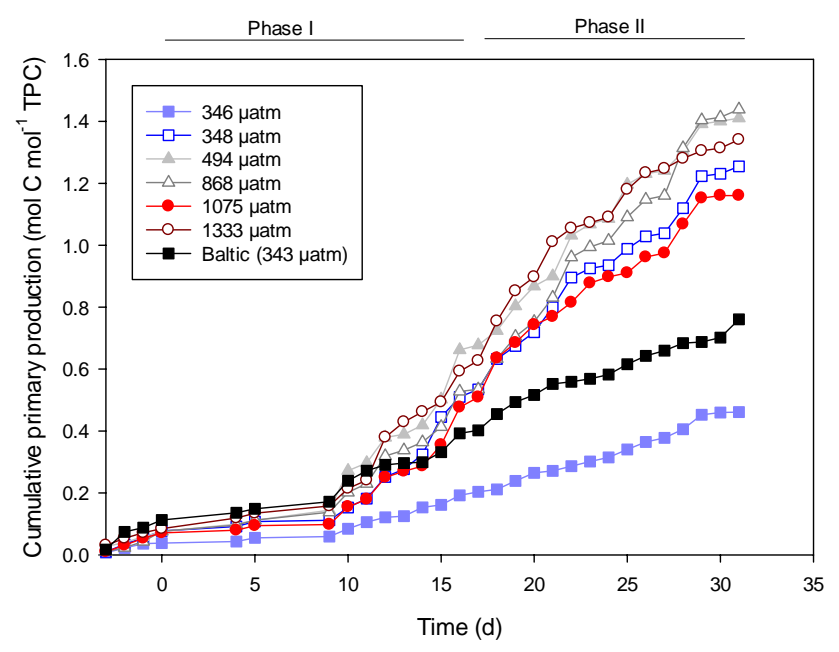

Figure 4. The cumulative primary production in the different $f \mathrm{CO}_{2}$ treatments normalized to TPC in the euphotic zone. The $f \mathrm{CO}_{2}$ ( $\mu \mathrm{atm})$ were the average measured over the duration of the experiment. The two lowest $f \mathrm{CO}_{2}$ treatments (346 and $348 \mu \mathrm{atm}$ ) were controls without any $\mathrm{CO}_{2}$ addition. The two phases of the experiment are indicated by the horizontal bars on top.

surements for the M1 bag must be an underestimate. Bacterial production during Phase II was highest in the ambient $\mathrm{CO}_{2}$, in particular in M1 (Hornick et al., 2016), and could partly be the reason for the elevated respiration rate in this mesocosm bag.

Having the respiration incubation at a fixed temperature might have caused a slight bias as there was varying thermal stratification throughout the experiment and the temperature was not even throughout the mesocosm bags. A better approach would have been to have respiration incubations in temperatures above and below the thermocline, but logistical constraints prevented us from doing this.

Another factor that could have influenced our incubations is UV light, which is a known inhibitor of primary production (Vincent and Roy, 1993), and elevated $\mathrm{CO}_{2}$ concentration may increase the sensitivity to UV light (Sobrino et al., 2009). Additionally, UV light reduces the release of DOC by phytoplankton, in particular at high $\mathrm{CO}_{2}$ concentration (Sobrino et al., 2014), but also causes photochemical mineralization of dissolved organic matter (DOM; Vahatalo and Jarvinen, 2007). Both DOC release and DOM breakdown may have implications for bacterial production and nutrient cycling. The mesocosm bags were made in a material absorbing UV light (thermoplastic polyurethane), whereas our primary production incubations were done in glass vials (transmitting some UV light) moored outside the mesocosm bags. The difference in UV transmittance could have produced a bias in the primary production measurements. However, the DOM concentration in the Baltic Sea is very high compared with most other oceans and coastal seas (Hoikkala et al., 2015). Most of this is terrestrial-derived, refractory DOM, which ef- fectively absorbs in the UV region, and typically the depth at which $1 \%$ of UVB remains is $<50 \mathrm{~cm}$ (Piazena and Häder, 1994). UVA penetrates a little deeper and may have affected slightly the incubation platform moored at $2 \mathrm{~m}$ depth, but we do not believe that UV light caused major inhibition of our primary production measurements or affected phytoplankton DOC production.

\subsection{Effect of $\mathrm{CO}_{2}$ on the balance between respiration and carbon fixation}

Increased $\mathrm{CO}_{2}$ concentration has increased carbon fixation in some studies (Egge et al., 2009; Engel et al., 2013). This was not observed in this study, but the higher Chl $a$, TPC and DOC in the high- $\mathrm{CO}_{2}$ treatments at the end of the experiment (Paul et al., 2015) could have been caused by the lower respiration rate in the highest $\mathrm{CO}_{2}$-enriched mesocosms, rather than increased primary production. Bacterial production was higher in the low $\mathrm{CO}_{2}$ after $t 20$ during this experiment (Hornick et al., 2016), which fits with the higher respiration rate at ambient $\mathrm{CO}_{2}$ concentration. The biomass of the smallest plankton size fraction $(<4 \mu \mathrm{m}$, not counted by microscope) increased in relative importance with $\mathrm{CO}_{2}$ addition in the latter part of the experiment, in particular two groups of picoeukaryotes (Crawfurd et al., 2016), and seems to have benefitted most by elevated $\mathrm{CO}_{2}$ concentration, similar to findings in the Arctic (Brussaard et al., 2013). Temporal changes in bacterial abundances followed largely that of phytoplankton biomass, and there were significant increases in viral lysis rates in the high- $\mathrm{CO}_{2}$ treatment (Crawfurd et al., 2016). This was most likely a consequence of higher abundances of picoeukaryotes and points towards a more productive but regenerative system (Crawfurd et al., 2016).

This study is, to our knowledge, the first one describing reduced respiration rates with ocean acidification on a plankton community scale. There are relatively few measurements of community respiration in ocean acidification experiments, and existing studies have revealed no specific responses in respiration (Egge et al., 2009; Tanaka et al., 2013; Mercado et al., 2014). Some of these studies have been relatively short ( $<2$ weeks) compared to the current study. Our results revealed a $\mathrm{CO}_{2}$ effect only 2 weeks into the experiment, suggesting that potential effects may have been present but remained below the detection limits in previous studies.

The effect of increasing $\mathrm{CO}_{2}$ concentration on respiration has mostly been documented for single species. For example, the copepod Centropages tenuiremis ( $\mathrm{Li}$ and Gao, 2012) and the diatom Phaeodactylum tricornutum (Wu et al., 2010) exhibited increased respiration rates in a high$\mathrm{CO}_{2}$ environment ( $\geq 1000 \mu \mathrm{atm} f \mathrm{CO}_{2}$ ), contrary to our findings. However, these types of studies have revealed different responses even when comparing different populations of the same species (Thor and Oliva, 2015), and any interpolation from single-species, laboratory studies should be carried out with great caution. The larger-scale, mesocosm ap- 


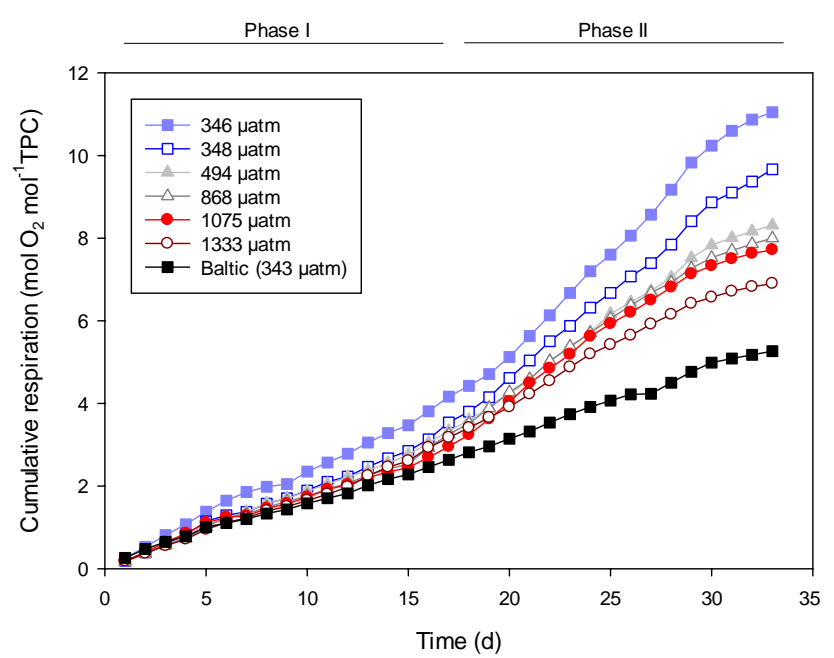

Figure 5. The cumulative respiration in the different $f \mathrm{CO}_{2}$ treatments normalized to TPC. The $f \mathrm{CO}_{2}$ ( $\mu$ atm) was the average measured over the duration of the experiment. The two lowest $f \mathrm{CO}_{2}$ treatments (346 and $348 \mu \mathrm{atm}$ ) were controls without any $\mathrm{CO}_{2}$ addition. The two phases of the experiment are indicated by the horizontal bars on top.

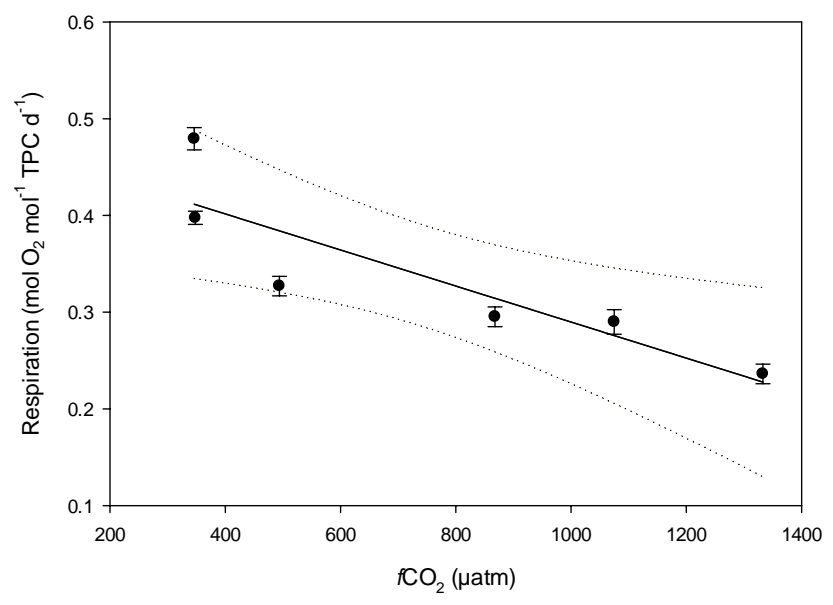

Figure 6. The respiration rate normalized to TPC, in the different $f \mathrm{CO}_{2}$ treatments during the latter half of the experiment ( $\left.t 20-t 31\right)$. Respiration was estimated by linear regression from the data presented in Fig. 4 from the time when an effect of increased $\mathrm{CO}_{2}$ concentration was first observed. The error bars represent standard error (SE) of the residuals from the linear regression. The solid line represents the linear regression (slope $-0.0002 ; p=0.02 ; R^{2}=0.77$ ) and dotted lines the $95 \%$ confidence intervals.

proach taken here has the advantage that the whole plankton community and possible interacting effects between different components of the food web are included.

For primary producers in aquatic environment, changes in carbonate chemistry speciation affect the availability of the sole substrate, i.e., $\mathrm{CO}_{2}$, at the site of photosynthetic carbon fixation. At present, marine waters typically have a $\mathrm{pH}$ of 8 or above, and most of the carbon is in the form of bicarbonate $\left(\mathrm{HCO}_{3}^{-}\right)$. Many phytoplankton groups have developed carbon concentrating mechanisms (CCMs) as a way to increase substrate availability at the site of carbon fixation (Singh et al., 2014), reducing the cost of growth (Raven, 1991). For phytoplankton with $\mathrm{CCMs}$, increased $\mathrm{CO}_{2}$ availability would suppress the CCM, freeing resources for growth, in particular under light-limiting conditions (Beardall and Giordano, 2002). There are examples of experiments with ocean acidification that have indicated downregulation of CCM (Hopkinson et al., 2010) and the photosynthetic apparatus (Sobrino et al., 2014), which could reduce respiration in phytoplankton.

The intracellular $\mathrm{pH}$ can be highly variable between different cellular compartments and organelles, but in the cytosol the $\mathrm{pH}$ is normally close to neutral $(\mathrm{pH} \sim 7.0)$ and is to a large extent independent of the external $\mathrm{pH}$ (Roos and Boron, 1981). In plants, animals and also bacteria, there is a complex set of $\mathrm{pH}$ regulatory mechanisms that are fundamentally controlled by physiological processes such as membrane transport of $\mathrm{H}^{+}$or $\mathrm{OH}^{-}$and intracellular metabolism (Smith and Raven, 1979; Kurkdjian and Guern, 1989). Internal pH regulation can be a considerable part of baseline respiration (Pörtner et al., 2000). With ocean acidification, the external $\mathrm{pH}$ becomes closer to the intracellular $\mathrm{pH}$, and this might reduce the metabolic cost (respiration) related to internal $\mathrm{pH}$ regulation. Teira et al. (2012) studied the effect of elevated $\mathrm{CO}_{2}$ concentration on two bacterial cultures and found reduced respiration in one of the two in a high- $\mathrm{CO}_{2}$ environment $\left(1000 \mu \mathrm{atm} \mathrm{CO}_{2}\right)$, and they suggest reduced metabolic cost for internal $\mathrm{pH}$ regulation as a possible mechanism. However, the other strain did not have any change in respiration rate and more studies of the effect of changed external $\mathrm{pH}$ on membrane transport are needed (Taylor et al., 2012). There might additionally be considerable difference between marine organisms depending on, for example, size, metabolic activity and growth rates, which directly affect $\mathrm{pH}$ in the diffusive boundary layer surrounding the organism (Flynn et al., 2012).

Judging from the importance of the smallest size class in this study, bacterial and picophytoplankton community (Crawfurd et al., 2016) and bacterial production (Hornick et al., 2016), the decreased respiration at higher $\mathrm{CO}_{2}$ concentration was probably mostly due to reduced picoplankton respiration. The underlying mechanisms behind the reduced respiration are unclear, and this is an underexplored research avenue that deserves further study.

\subsection{Interacting effects and community composition}

Our measurements outside the mesocosm bags demonstrate that plankton physiology and community composition can have a big impact on both primary production and respiration. The plankton community was relatively uniform across all mesocosm bags. Unfortunately, we do not have any community data from outside the mesocosm bags, but 
the amplitude of Chl $a$ dynamics was different, with an upwelling event leading to a doubling of the Chl $a$ concentration ( $\sim 5 \mu \mathrm{g} \mathrm{Chl} a \mathrm{~L}^{-1}$ ) around $t 17$ (Paul et al., 2015). This suggests a different availability of inorganic nutrients and different plankton community as other environmental variables such as light and temperature were similar both inside and outside the mesocosm bags, except that UV light was absent inside the mesocosm bags. The carbon-normalized respiration rate outside the mesocosm bags (with ambient $f \mathrm{CO}_{2}$ ) was approximately half of the respiration rates in the controls with the same average $f \mathrm{CO}_{2}$, and also absolute respiration was clearly lower during Phase II, when nitrate was depleted inside the bags and plankton biomass was decreasing. However, the $\mathrm{fCO}_{2}$ was more variable outside the mesocosm bags compared with the control bags (although their averages were similar), and the $f \mathrm{CO}_{2}$ increased throughout Phase II outside the bags to approximately $700 \mu$ atm by $t 31$ (Paul et al., 2015). This could have influenced the carbon normalized respiration, which started to deviate outside the bags during Phase II, but it could also have been interacting effects of different environmental changes (different nutrient dynamics) leading to this lower respiration rate. An often overlooked aspect is the importance of the plankton community composition, which can be more important than changes in external factors (Verity and Smetacek, 1996; Eggers et al., 2014).

Bacterial production (Grossart et al., 2006) and bacterial degradation of polysaccharides (Piontek et al., 2010) have been demonstrated to increase under elevated $\mathrm{CO}_{2}$ concentration, contrary to the findings during this experiment (Hornick et al., 2016). All of these responses are to a large extent dependent on the plankton community composition. For example, the increased bacterial production observed in a mesocosm study in a Norwegian fjord was probably a response to increased carbon availability produced by phytoplankton (Grossart et al., 2006). DOC production by phytoplankton is determined by the physiological state and the composition of the community (Thornton, 2014); in particular, diatoms have been intensively studied in this respect and are known to be important DOC producers (Hoagland et al., 1993). Shifts in the phytoplankton community may alter the DOC production (Spilling et al., 2014), and any shifts in the plankton community composition, caused by ocean acidification, may have greater effects on ecosystem functioning than any direct effect of increasing $f \mathrm{CO}_{2} /$ decreasing $\mathrm{pH}$ (Eggers et al., 2014).

It is evident that there were other variables that influence the physiology of the plankton community as a whole outside the mesocosms. Changes in community composition and nutrient availability seem the most plausible reasons. A better understanding of how different physical, chemical and biological factors interact with each other is needed in order to improve our understanding of how marine ecosystems change under the influence of a range of environmental pressures.

\subsection{Potential implications for carbon cycling}

A lot of attention during past decades has been directed to understanding the biological carbon pump, as it is a key mechanism for sequestering atmospheric $\mathrm{CO}_{2}$. The potential export is ultimately determined by gross primary production minus total community respiration. Even small changes in the production or loss term of this equation have the potential to greatly affect biogeochemical cycling of carbon.

The exported carbon decreased during the experiment. Part of this decrease was probably due to sinking of existing organic material at the start of the experiment and can be seen as the reduction in TPC. However, this also coincided with the shift towards increased dominance of picoplankton. Size is a key parameter determining sinking speed, and picoplankton is very inefficient in transporting carbon out of the euphotic layer (Michaels and Silver, 1988). The shift towards smaller size classes was likely also contributing to the reduction in exported carbon.

The $40 \%$ reduction in respiration with increasing $f \mathrm{CO}_{2}$ found in our study could have great implications for net export of carbon in the future ocean. There is, however, uncertainty in the results, in particular that the measured net carbon fixation under increased $\mathrm{CO}_{2}$ was not higher than in the controls. In the case of reduced respiration, an increase in net primary production can be expected, as loss rates are reduced. That the measured carbon fixation was not evidently different between treatments could be due to similar reduction in gross primary production, as indicated by carbon flux estimates (Spilling et al., 2016a). Alternatively, the measurement uncertainty in our small-scale incubations $(8 \mathrm{~mL})$, involving several pipetting steps, was likely higher than the respiration measurements, which could have prevented us from picking up any $\mathrm{CO}_{2}$ effect on primary production. Another complicating factor is what the ${ }^{14} \mathrm{C}$ method is actually measuring (Sakshaug et al., 1997; Falkowski and Raven, 2013). The consensus seems to be somewhere between gross and net production, but leaning towards net production with long incubation times (Marra, 2009).

There was evidence of a positive $\mathrm{CO}_{2}$ effect on the amount of Chl $a$, TPC and DOC pools (Paul et al., 2015), suggesting that the reduced respiration does translate into higher net carbon fixation. This effect was seen from the latter part of Phase II and the trend continued after $t 31$ (these variables were sampled until $t 43$ ). This increased net carbon fixation did not, however, affect carbon export as there was no detectable difference in the sinking flux measurements (Table 1 and Paul et al., 2015). The results suggest that the increased carbon fixation resulted in the smallest size fraction of TPC not being exported and/or ending up in the dissolved organic carbon pool. Further support for this conclusion is presented in Paul et al. (2015), Crawfurd et al. (2016) and Lischka et al. (2015).

In conclusion, this study suggests that elevated $\mathrm{CO}_{2}$ reduced respiration, which in turn increased net carbon fix- 
ation. However, the increased primary production did not translate into increased carbon export, and consequently did not work as a negative feedback mechanism for increasing atmospheric $\mathrm{CO}_{2}$ concentration.

\section{Data availability}

The primary production and respiration data can be found in Spilling et al. (2016b; doi: 10.1594/PANGAEA.863933).

Most other variables from the experiment (e.g. total particulate carbon) can be found in Paul et al. (2016; doi:10.1594/PANGAEA.863032).

\section{The Supplement related to this article is available online at doi:10.5194/bg-13-4707-2016-supplement.}

Acknowledgements. We would like to thank all of the staff at Tvärminne Zoological Station for great help during this experiment and Michael Sswat for carrying out the TPC filtrations. We also gratefully acknowledge the captain and crew of R/V ALKOR (AL394 and AL397) for their work transporting, deploying and recovering the mesocosms. The collaborative mesocosm campaign was funded by BMBF projects BIOACID II (FKZ 03F06550) and SOPRAN Phase II (FKZ 03F0611). Additional financial support for this study came from the Academy of Finland (KS - Decisions no. 259164 and 263862) and the Walter and Andrée de Nottbeck Foundation (KS, NV).

Edited by: C. P. D. Brussaard

Reviewed by: P. Neale and one anonymous referee

\section{References}

Beardall, J. and Giordano, M.: Ecological implications of microalgal and cyanobacterial $\mathrm{CO}_{2}$ concentrating mechanisms, and their regulation, Funct. Plant. Biol., 29, 335-347, 2002.

Beldowski, J., Löffler, A., Schneider, B., and Joensuu, L.: Distribution and biogeochemical control of total $\mathrm{CO}_{2}$ and total alkalinity in the Baltic Sea, J. Marine Syst., 81, 252-259, 2010.

Bermúdez, J. R., Winder, M., Stuhr, A., Almén, A. K., EngströmÖst, J., and Riebesell, U.: Effect of ocean acidification on the structure and fatty acid composition of a natural plankton community in the Baltic Sea, Biogeosciences Discuss., doi:10.5194/bg-2015-669, in review, 2016.

Boxhammer, T., Bach, L. T., Czerny, J., and Riebesell, U.: Technical note: Sampling and processing of mesocosm sediment trap material for quantitative biogeochemical analysis, Biogeosciences, 13, 2849-2858, doi:10.5194/bg-13-2849-2016, 2016.

Brussaard, C. P. D., Noordeloos, A. A. M., Witte, H., Collenteur, M. C. J., Schulz, K., Ludwig, A., and Riebesell, U.: Arctic microbial community dynamics influenced by elevated $\mathrm{CO} 2$ levels, Biogeosciences, 10, 719-731, doi:10.5194/bg-10-719-2013, 2013.
Crawfurd, K. J., Brussaard, C. P. D., and Riebesell, U.: Shifts in the microbial community in the Baltic Sea with increasing $\mathrm{CO}_{2}$, Biogeosciences Discuss., doi:10.5194/bg-2015-606, in review, 2016.

Ducklow, H. W., Steinberg, D. K., and Buesseler, K. O.: Upper ocean carbon export and the biological pump, Oceanography, 14, 50-58, 2001.

Dunne, J. P., Sarmiento, J. L., and Gnanadesikan, A.: A synthesis of global particle export from the surface ocean and cycling through the ocean interior and on the seafloor, Global Biogeochem. Cy., 21, GB4006, doi:10.1029/2006GB002907, 2007.

Egge, J. K., Thingstad, T. F., Larsen, A., Engel, A., Wohlers, J., Bellerby, R. G. J., and Riebesell, U.: Primary production during nutrient-induced blooms at elevated $\mathrm{CO}_{2}$ concentrations, Biogeosciences, 6, 877-885, doi:10.5194/bg-6-877-2009, 2009.

Eggers, S. L., Lewandowska, A. M., Barcelos e Ramos, J., BlancoAmeijeiras, S., Gallo, F., and Matthiessen, B.: Community composition has greater impact on the functioning of marine phytoplankton communities than ocean acidification, Glob. Change Biol., 20, 713-723, 2014.

Engel, A., Borchard, C., Piontek, J., Schulz, K. G., Riebesell, U., and Bellerby, R.: $\mathrm{CO}_{2}$ increases ${ }^{14} \mathrm{C}$ primary production in an Arctic plankton community, Biogeosciences, 10, 1291-1308, doi:10.5194/bg-10-1291-2013, 2013.

Falkowski, P. G. and Raven, J. A.: Aquatic photosynthesis; Second edition, Princeton University Press, Princeton, 501 pp., 2013.

Flynn, K. J., Blackford, J. C., Baird, M. E., Raven, J. A., Clark, D. R., Beardall, J., Brownlee, C., Fabian, H., and Wheeler, G. L.: Changes in $\mathrm{pH}$ at the exterior surface of plankton with ocean acidification, Nature Climate Change, 2, 510-513, 2012.

Gargas, E.: A manual for phytoplankton primary production studies in the Baltic, The Baltic Marine Biologist, Hørsholm, Denmark, 88 pp., 1975.

Grossart, H.-P., Allgaier, M., Passow, U., and Riebesell, U.: Testing the effect of $\mathrm{CO}_{2}$ concentration on the dynamics of marine heterotrophic bacterioplankton, Limnol. Oceanogr., 51, 1-11, 2006.

Hällfors, G.: Checklist of Baltic Sea phytoplankton species, Baltic Sea Environment Proceedings No. 95, HELCOM, Helsinki, 208 pp., 2004.

Hoagland, K. D., Rosowski, J. R., Gretz, M. R., and Roemer, S. C.: Diatom extracellular polymeric substances: function, fine structure, chemistry, and physiology, J. Phycol., 29, 537-566, 1993.

Hoikkala, L., Kortelainen, P., Soinne, H., and Kuosa, H.: Dissolved organic matter in the Baltic Sea, J. Marine Syst., 142, 47-61, 2015.

Hopkinson, B. M., Xu, Y., Shi, D., McGinn, P. J., and Morel, F. M.: The effect of $\mathrm{CO}_{2}$ on the photosynthetic physiology of phytoplankton in the Gulf of Alaska, Limnol. Oceanogr., 55, 20112024, 2010.

Hoppenrath, M., Elbrächter, M., and Drebes, G.: Marine Phytoplankton: Selected MicrophytoplanktonSpecies from the North Sea around Helgoland and Sylt, Schweizerbart Science Publishers, Stuttgart, Germany, 264 pp., 2009.

Hornick, T., Bach, L. T., Crawfurd, K. J., Spilling, K., Achterberg, E. P., Brussaard, C. P. D., Riebesell, U., and Grossart, H.-P.: Ocean acidification indirectly alters trophic interaction of heterotrophic bacteria at low nutrient conditions, Biogeosciences Discuss., doi:10.5194/bg-2016-61, in review, 2016.

Johnson, M. D., Tengs, T., Oldach, D., and Stoecker, D. K.: Sequestration, performance, and functional control of cryptophyte 
plastids in the ciliate Myrionecta rubra (ciliophora), J. Phycol., 42, 1235-1246, 2006.

Kanoshina, I., Lips, U., and Leppänen, J.-M.: The influence of weather conditions (temperature and wind) on cyanobacterial bloom development in the Gulf of Finland (Baltic Sea), Harmful Algae, 2, 29-41, 2003.

Kivi, K., Kaitala, S., Kuosa, H., Kuparinen, J., Leskinen, E., Lignell, R., Marcussen, B., and Tamminen, T.: Nutrient limitation and grazing control of the Baltic plankton community during annual succession, Limnol. Oceanogr., 38, 893-905, 1993.

Kraberg, A., Baumann, M., and Dürselen, C.-D.: Coastal phytoplankton: photo guide for Northern European seas, Pfeil, München, 2010.

Kurkdjian, A., and Guern, J.: Intracellular pH: measurement and importance in cell activity, Annu. Rev. Plant Biol., 40, 271-303, 1989.

Le Quéré, C., Raupach, M. R., Canadell, J. G., Marland, G., Bopp, L., Ciais, P., Conway, T. J., Doney, S. C., Feely, R. A., and Foster, P.: Trends in the sources and sinks of carbon dioxide, Nat. Geosci., 2, 831-836, 2009.

$\mathrm{Li}, \mathrm{W}$. and Gao, K.: A marine secondary producer respires and feeds more in a high $\mathrm{CO}_{2}$ ocean, Mar. Pollut. Bull., 64, 699-703, 2012.

Lischka, S., Bach, L. T., Schulz, K.-G., and Riebesell, U.: Microand mesozooplankton community response to increasing $\mathrm{CO}_{2}$ levels in the Baltic Sea: insights from a large-scale mesocosm experiment, Biogeosciences Discuss., 12, 20025-20070, doi:10.5194/bgd-12-20025-2015, 2015.

Mackey, K. R., Morris, J. J., Morel, F. M., and Kranz, S. A.: Response of photosynthesis to ocean acidification, Oceanography, 28, 74-91, 2015.

Margalef, R.: Life-forms of phytoplankton as survival alternatives in an unstable environment, Oceanol. Ac., 1, 493-509, 1978.

Marra, J.: Net and gross productivity: weighing in with ${ }^{14} \mathrm{C}$, Aquat. Microb. Ecol., 56, 123-131, 2009.

Menden-Deuer, S. and Lessard, E. J.: Carbon to volume relationships for dinoflagellates, diatoms, and other protist plankton, Limnol. Oceanogr., 45, 569-579, 2000.

Mercado, J., Sobrino, C., Neale, P., Segovia, M., Reul, A., Amorim, A., Carrillo, P., Claquin, P., Cabrerizo, M., and León, P.: Effect of $\mathrm{CO}_{2}$, nutrients and light on coastal plankton, II. Metabolic rates, Aquat. Biol., 22, 43-57, 2014.

Michaels, A. F. and Silver, M. W.: Primary production, sinking fluxes and the microbial food web, Deep-Sea Res., 35, 473-490, 1988.

Nausch, M., Bach, L. T., Czerny, J., Goldstein, J., Grossart, H.-P., Hellemann, D., Hornick, T., Achterberg, E. P., Schulz, K.-G., and Riebesell, U.: Effects of $\mathrm{CO}_{2}$ perturbation on phosphorus pool sizes and uptake in a mesocosm experiment during a low productive summer season in the northern Baltic Sea, Biogeosciences, 13, 3035-3050, doi:10.5194/bg-13-3035-2016, 2016.

Olenina, I., Hajdu, S., Edler, L., Andersson, A., Wasmund, N., Busch, S., Göbel, J., Gromisz, S., Huseby, S., Huttunen, M., Jaanus, A., Kokkonen, P., Ledaine, I., and Niemkiewicz, E.: Biovolumes and size-classes of phytoplankton in the Baltic Sea, Balt. Sea Environ. Proc., HELCOM, 144 pp., 2006.

Orr, J. C.: Recent and future changes in ocean carbonate chemistry, in: Ocean acidification, edited by: Gattuso, J.-P. and Hansson, L., Oxford University Press, Oxford, 41-66, 2011.
Paul, A. J., Bach, L. T., Schulz, K.-G., Boxhammer, T., Czerny, J., Achterberg, E. P., Hellemann, D., Trense, Y., Nausch, M., Sswat, M., and Riebesell, U.: Effect of elevated $\mathrm{CO}_{2}$ on organic matter pools and fluxes in a summer Baltic Sea plankton community, Biogeosciences, 12, 6181-6203, doi:10.5194/bg-12-6181-2015, 2015.

Paul, A., Schulz, K. G., Achterberg, E. P., Hellemann, D., Nausch, M., Boxhammer, T., Bach, L. T., and Trense, Y.: KOSMOS Finland 2012 mesocosm study: carbonate chemistry, particulate and dissolved matter pools, and phytoplankton community composition using marker pigments (CHEMTAX), doi:10.1594/PANGAEA.863032, 2016.

Piazena, H. and Häder, D. P.: Penetration of solar UV irradiation in coastal lagoons of the southern Baltic Sea and its effect on phytoplankton communities, Photochem. Photobiol., 60, 463-469, 1994.

Piontek, J., Lunau, M., Händel, N., Borchard, C., Wurst, M., and Engel, A.: Acidification increases microbial polysaccharide degradation in the ocean, Biogeosciences, 7, 1615-1624, doi:10.5194/bg-7-1615-2010, 2010.

Pörtner, H., Bock, C., and Reipschlager, A.: Modulation of the cost of pHi regulation during metabolic depression: a (31) P-NMR study in invertebrate (Sipunculus nudus) isolated muscle, J. Exp. Biol., 203, 2417-2428, 2000.

Raateoja, M., Seppala, J., Kuosa, H., and Myrberg, K.: Recent changes in trophic state of the Baltic Sea along SW coast of Finland, Ambio, 34, 188-191, 2005.

Raven, J. A.: Physiology of inorganic C acquisition and implications for resource use efficiency by marine phytoplankton: relation to increased $\mathrm{CO}_{2}$ and temperature, Plant Cell Environ., 14, 779-794, 1991.

Riebesell, U. and Tortell, P. D.: Effects of ocean acidification on pelagic organisms and ecosystems, in: Ocean acidification, edited by: Gattuso, J.-P. and Hansson, L., Oxford University Press, Oxford, 99-121, 2011.

Riebesell, U., Czerny, J., von Bröckel, K., Boxhammer, T., Büdenbender, J., Deckelnick, M., Fischer, M., Hoffmann, D., Krug, S. A., Lentz, U., Ludwig, A., Muche, R., and Schulz, K. G.: Technical Note: A mobile sea-going mesocosm system - new opportunities for ocean change research, Biogeosciences, 10, 18351847, doi:10.5194/bg-10-1835-2013, 2013.

Robinson, C. and Williams, P. B.: Respiration and its measurement in surface marine waters, in: Respiration in aquatic ecosystems, edited by: Giorgio, P. A. and Williams, P. B., Oxford University Press, Oxford, 147-181, 2005.

Roos, A. and Boron, W. F.: Intracellular pH, Am. Physiol. Soc., 61, 296-434, 1981.

Sakshaug, E., Bricaud, A., Dandonneau, Y., Falkowski, P. G., Kiefer, D. A., Legendre, L., Morel, A., Parslow, J., and Takahashi, M.: Parameters of photosynthesis: definitions, theory and interpretation of results, J. Plankton Res., 19, 1637-1670, 1997.

Savchuk, O. P.: Resolving the Baltic Sea into seven subbasins: N and P budgets for 1991-1999, J. Mar. Syst., 56, 1-15, 2005.

Setälä, O., Kuuppo, P., Ekebom, J., Kuosa, H., and Patterson, D.: Workbook on protist ecology and taxonomy. Proceedings from the 1st Workshop on Protistology at Tvärminne Zoological Station, Yliopistopaino, Helsinki, 161 pp., 1992.

Sharp, J.: Improved analysis for particulate organic carbon and nitrogen from seawater, Limnol. Oceanogr., 19, 984-989, 1974. 
Siegenthaler, U. and Sarmiento, J.: Atmospheric carbon dioxide and the ocean, Nature, 365, 119-125, 1993.

Singh, S. K., Sundaram, S., and Kishor, K.: Photosynthetic microorganisms: Mechanism for carbon concentration, Springer, Berlin, 131 pp., 2014.

Smayda, T. J. and Reynolds, C. S.: Community assembly in marine phytoplankton: application of recent models to harmful dinoflagellate blooms, J. Plankton Res., 23, 447-461, 2001.

Smith, F. and Raven, J. A.: Intracellular $\mathrm{pH}$ and its regulation, Annu. Rev. Plant Physiol., 30, 289-311, 1979.

Sobrino, C., Neale, P., Phillips-Kress, J., Moeller, R., and Porter, J.: Elevated $\mathrm{CO}_{2}$ increases sensitivity to ultraviolet radiation in lacustrine phytoplankton assemblages, Limnol. Oceanogr., 54, 2448-2459, 2009.

Sobrino, C., Segovia, M., Neale, P., Mercado, J., García-Gómez, C., Kulk, G., Lorenzo, M., Camarena, T., van de Poll, W., Spilling, K., and Ruan, Z.: Effect of $\mathrm{CO}_{2}$, nutrients and light on coastal plankton, IV. Physiological responses, Aquat. Biol., 22, 77-93, 2014.

Spilling, K.: Dense sub-ice bloom of dinoflagellates in the Baltic Sea, potentially limited by high pH, J. Plankton Res., 29, 895901, 2007.

Spilling, K., Kremp, A., Klais, R., Olli, K., and Tamminen, T.: Spring bloom community change modifies carbon pathways and $\mathrm{C}: \mathrm{N}: \mathrm{P}:$ Chl $a$ stoichiometry of coastal material fluxes, Biogeosciences, 11, 7275-7289, doi:10.5194/bg-11-7275-2014, 2014.

Spilling, K., Schulz, K. G., Paul, A. J., Boxhammer, T., Achterberg, E. P., Hornick, T., Lischka, S., Stuhr, A., Bermúdez, R., Czerny, J., Crawfurd, K., Brussaard, C. P. D., Grossart, H.-P., and Riebesell, U.: Effects of ocean acidification on pelagic carbon fluxes in a mesocosm experiment, Biogeosciences Discuss., doi:10.5194/bg-2016-56, in review, 2016a.

Spilling, K., Paul, A., Virkkala, N., Hastings, T., Lischka, S., Stuhr, A., Bermúdez, R., Czerny, J., Boxhammer, T., Schulz, K. G., Ludwig, A., and Riebesell, U.: KOSMOS Finland 2012 mesocosm study: primary production and respiration, doi:10.1594/PANGAEA.863933, 2016 b.

Steeman-Nielsen, E.: The use of radioactive carbon for measuring organic production in the sea, J. Cons. Int. Explor. Mer., 18, 117140, 1952.

Suikkanen, S., Laamanen, M., and Huttunen, M.: Long-term changes in summer phytoplankton communities of the open northern Baltic Sea, Estuar. Coast Shelf Sci., 71, 580-592, 2007.

Tanaka, T., Alliouane, S., Bellerby, R. G. B., Czerny, J., de Kluijver, A., Riebesell, U., Schulz, K. G., Silyakova, A., and Gattuso, J.-P.: Effect of increased $p \mathrm{CO}_{2}$ on the planktonic metabolic balance during a mesocosm experiment in an Arctic fjord, Biogeosciences, 10, 315-325, doi:10.5194/bg-10-315-2013, 2013.

Taylor, A. R., Brownlee, C., and Wheeler, G. L.: Proton channels in algae: reasons to be excited, Trends Plant Sci., 17, 675-684, 2012.

Teira, E., Fernández, A., Álvarez-Salgado, X. A., García-Martín, E. E., Serret, P., and Sobrino, C.: Response of two marine bacterial isolates to high $\mathrm{CO}_{2}$ concentration, Mar. Ecol.-Prog. Ser., 453, 27-36, 2012.
Telesh, I., Postel, L., Heerkloss, R., Mironova, E., and Skarlato, S.: Zooplankton of the open Baltic Sea: Extended Atlas. Marine Science Reports, Leibniz institute for Baltic Sea research, Warnemünde, 290, 2009.

Thor, P. and Oliva, E. O.: Ocean acidification elicits different energetic responses in an Arctic and a boreal population of the copepod Pseudocalanus acuspes, Mar. Biol., 162, 799-807, 2015.

Thornton, D. C.: Dissolved organic matter (DOM) release by phytoplankton in the contemporary and future ocean, Eur. J. Phycol., 49, 20-46, 2014.

Tomas, C. R.: Identifying marine phytoplankton, Academic press, NewYork, 858 pp., 1997.

Utermöhl, H.: Zur Vervollkommnung der quantitativen Phytoplanktonmethodik, Mitteilungen der Internationale Vereinigung fur Theoretische und Angewandte Limnologie, 9, 1-38, 1958.

Vähätalo, A. V. and Jarvinen, M.: Photochemically produced bioavailable nitrogen from biologically recalcitrant dissolved organic matter stimulates production of a nitrogen-limited microbial food web in the Baltic Sea, Limnol. Oceanogr., 52, 132-143, 2007.

Verity, P., and Smetacek, V.: Organism life cycles, predation, and the structure of marine pelagic ecosystems, Mar. Ecol.-Prog. Ser., 130, 277-293, 1996.

Viitasalo, M., Vuorinen, I., and Saesmaa, S.: Mesozooplankton dynamics in the northern Baltic Sea: implications of variations in hydrography and climate, J. Plankton Res., 17, 1857-1878, 1995.

Vincent, W. F. and Roy, S.: Solar ultraviolet-B radiation and aquatic primary production: damage, protection, and recovery, Environ. Rev., 1, 1-12, 1993.

Volk, T. and Hoffert, M. I.: Ocean carbon pumps: analysis of relative strengths and efficiencies in ocean-driven atmospheric $\mathrm{CO}_{2}$ changes, in: The carbon cycle and atmospheric $\mathrm{CO}_{2}$ : natural variations Archean to Present, edited by: Sundquist, E. T. and Broecker, W. S., American Geophysical Union, Washington, 99110, 1985.

Wiebe, P. H.: Functional regression equations for zooplankton displacement volume, wet weight, dry weight, and carbon: a correction, Fish. B., 86, 833-835, 1988.

Wu, Y., Gao, K., and Riebesell, U.: $\mathrm{CO}_{2}$-induced seawater acidification affects physiological performance of the marine diatom Phaeodactylum tricornutum, Biogeosciences, 7, 29152923, doi:10.5194/bg-7-2915-2010, 2010.

Zeebe, R. E. and Ridgwell, A.: Past changes of ocean carbonate chemistry, in: Ocean acidification, edited by: Gattuso, J.-P. and Hansson, L., Oxford University Press, Oxford, 1-28, 2011.

Zeebe, R. E., Zachos, J. C., Caldeira, K., and Tyrrell, T.: Carbon emissions and acidification, Science, 321, 51-52, 2008. 